\title{
Potential of Vetiver Grass for Wastewater Treatment
}

\author{
Alina Maharjan", Sadhana Pradhanang \\ Central Department of Environmental Science, Tribhuvan University, Nepal
}

Copyright $\bigcirc 2017$ by authors, all rights reserved. Authors agree that this article remains permanently open access under the terms of the Creative Commons Attribution License 4.0 International License

\begin{abstract}
Vetiver (Chrysopogonzizanioides) is a perennial bunch grass of the Poaceae family which is popularly known as Kush, and which are suitable for the disposal of leachate and effluents generated from landfill and wastewater treatment with super absorbent characteristics. This experimental study was carried out to assess the efficiency of Vetiver plants in the water of Bagmati River, close to Kirtipur's Laboratory School. Data for design parameters- $\mathrm{pH}$, Temperature, Conductivity, $\mathrm{BOD}_{5}$, Chloride, Nitrate, Phosphate, Hardness and Alkalinity- were collected regularly for a month. Vetiver plants were planted in three buckets with 7.5 liters of sampled water, while another bucket was kept as a control. In each of the three buckets, nine Vetiver plants were planted and physico-chemical parameters analyzed for one month at ten-day intervals. The result showed that on the one month, the overall concentration of $\mathrm{BOD}_{5}$, Chloride, Nitrate, Phosphate, Hardness and Alkalinity reduced by $71.03 \%$, $42.90 \%, 93.93 \%, 88.4 \%, 46.4 \%$ and $22.2 \%$ respectively. $\mathrm{pH}$ and temperature of wastewater showed slight change while electronic conductivity lowered to normal levels after treatment in the bucket. Vetiver plant seems very effective in treating polluted water having high phosphate and nitrate levels.
\end{abstract}

Keywords Bagmati, Vetiver, Chrysopogon zizanioides, Wastewater Treatment

\section{Introduction}

Water is one of the most important natural resources, and without which, life is impossible. About $70 \%$ of the world's surface consists of water. Nearly $70 \%$ of worldwide fresh water resources are used in agriculture and water comprises roughly $70 \%$ of the human body. In the history of our planet, water has played a crucial role not only in the emergence of life some 3.5 billion years ago, but also in the birth of the first great civilization that has been developed in the major river basins of the world like Egypt, India, China, Mesopotamia, between 3000 and 1500 BC (Stikker [1], 1998). Nepal is the richest country in water resources in Asia and second richest country in the world after Brazil with respect to the water resource. Being a mountainous country with snow-capped Himalaya Ranges and with large perennial rivers originating from, the water resources of Nepal are very immense. There are about 6,000 rivers with about $45,000 \mathrm{Km}$ lengths. The major rivers of Nepal are Mechi, Koshi, Bagmati, Karnali, Narayani, Gandaki and Mahakali.

Currently, the water quality is declining due to the contamination of various pollutants in water, which makes the water unsuitable for consumption and other usages. In simple words, clean water is becoming one of the biggest concerns of the twenty-first century. To solve the problems of water, various waste water treatment methods has been applied, but the existing and traditional wastewater treatment methods like Active Sludge treatment, Microbial treatment, Chemically Enhanced Primary Treatment (CEPT), Advanced Integrated Pond System (AIPS), Aerated and Non-Aerated lagoons, etc. are expensive and in most cases are either impractical or unsuitable for smaller communities and certain industries. Currently, low technique system like phytoremediation is used for the treatment of wastewater.

Phytoremediation use plants for the environmental restoration. It is an emerging clean up technology to exploit plant potentials to remediate soil and water contaminate with a variety of pollutant compound (Lasat [2], 2002). Phytoremediation is environmental friendly, inexpensive and can be carried out in polluted place. Phytoremediation has also been called green remediation, botano remediation; agro remediation and vegetative remediation (Erakhrumen[3], 2007).There are several plants suitable for wastewater treatment. Among them, Vetiver plant is one. Vetiver (Chrysopogon zizanioides) is a perennial bunchgrass of the Poaceae family, native to India. It is popularly known as khus. Vetiver grass was first recognized in 1995 for having "super absorbent" characteristics suitable for the disposal of leachate and effluent generated from landfill and wastewater treatment plants in Queensland, Australia. Chinese scientists later confirmed these results in 1997 and since then the Vetiver System has been used successfully for these purposes in Australia, China and Thailand (Truong [4], 2000). 
Vetiver can grow up to $150 \mathrm{~cm}(5 \mathrm{ft})$ high and form clumps as wide. The stems are tall and the leaves are long, thin, and rather rigid. The flowers are brownish-purple. The root system of vetiver is finely structured and very strong. It can grow $3 \mathrm{~m}(10 \mathrm{ft})$ to $4 \mathrm{~m}(13 \mathrm{ft})$ deep within the first year. Vetiver has no stolons nor rhizomes. It is non-invasive as it has sterile seeds. Because of all these characteristics, the vetiver plant is highly drought-tolerant and can help to protect soil against sheet erosion. In case of sediment deposition, new roots can grow out of buried nodes.

Due to the unique morphological and ecological characteristics, Vetiver grass has been effectively used for many applications such as steep slope stabilization and environmental protection. The utilization of vetiver system for wastewater treatment is new and innovative phytoremediation technology developed in Queensland by the Department of Natural Resources and Mines (NRM) (Truong and Hart [5], 2001).

In Nepal, Vetiver was first introduced by Sustainable Technology and Green Environment Nepal (STAGE Nepal), a non- profit and non-governmental organization in close collaboration with Nepal Vetiver Network (NPVN) and East-India Vetiver Network (EIVN) in April 2011.

\subsection{Statement of Problem}

With a rise in global populations, especially in third world and developing countries like Nepal, housing densities have significantly increased. Much of this housing is inadequately serviced by sewer systems. Thus, the major rivers and their tributaries are becoming the dumping sites of all kinds of domestic, industrial, medical, construction and other various kinds of wastes, due to which the center of our traditional values i.e. the river systems are being deteriorated day by day.

People in various nations have been involved in proper utilization of wastewater, yet they are not succeeded. Some of the best methods are used to treat the waste water. Since, modern technologies are very costly and require good technical knowledge on handling the process, not always feasible in the country like Nepal. The Bagmati river and their tributaries around Kathmandu Valley which are losing their originality and suffering for their stable existence due to the contamination by different kinds of anthropogenic sources like wastewater disposal from houses, schools, colleges, hospitals industries etc. As Bagmati River is considered as the source of Nepalese civilization and urbanization, the treatment of water of Bagmati became important. This study will help to determine the wastewater treatment efficiency of Vetiver plant in the water of Bagmati for one month. This case study would be helpful for bringing out a better solution for wastewater treatment.

\subsection{Objectives}

\subsubsection{General objectives}

To determine the wastewater treatment efficiency of
Vetiver plant in the water of Bagmati for one month.

\subsubsection{Specific Objectives}

a) To determine physical parameters of wastewater before and after treatments

b) To determine chemical ( $\mathrm{pH}$, Conductivity, Biological Oxygen Demand, Nitrate, Phosphate, Chloride, Hardness, Alkalinity) parameters of wastewater before and after treatments

\section{Materials and Methods}

\subsection{Study Area}

The Bagmati River runs through the Kathmandu Valley of Nepal and separates Kathmandu from Patan. It is considered as Holy River by both Hindus and Buddhists. A number of Hindu temples are located on the banks of Bagmati. The Bagmati River is also considered as the source of Nepalese civilization and urbanization. The Bagmati originates from the three headwater streams converge at Baghdwar. This lies above the southern edge of Shivapuri Hills about 15 kilometers northeast of Kathmandu. The river flows southwest about $10 \mathrm{~km}$ through terraced rice field in the Kathmandu Valley.
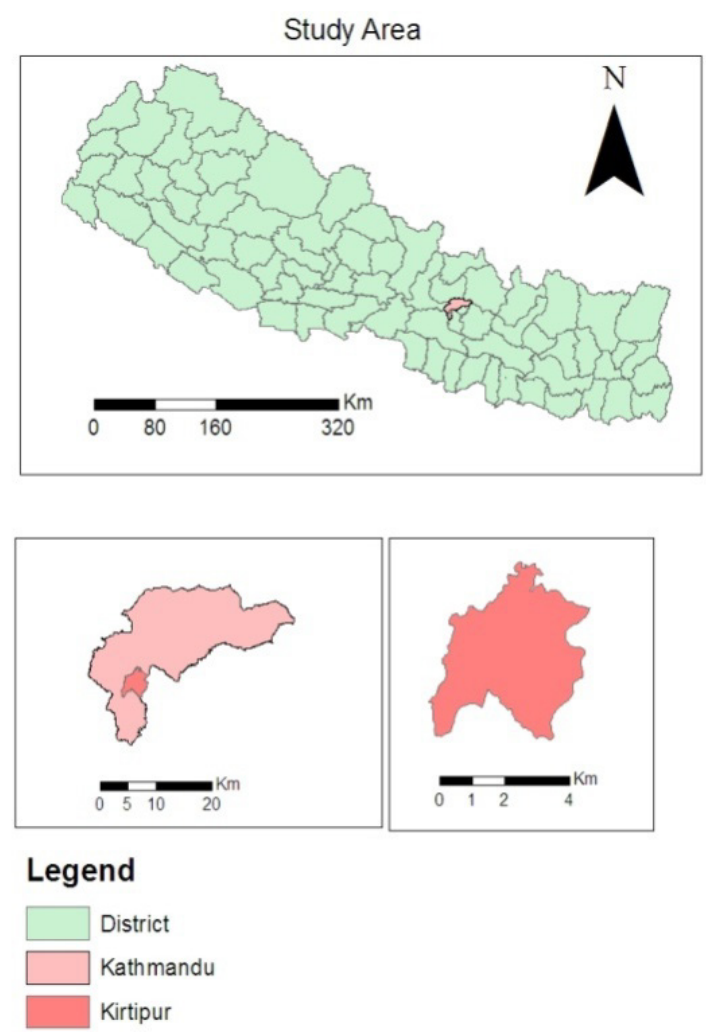

Figure 1. Map of Study Area (Sundarighat, Kirtipur)

The water sample was collected in January 6, 2016 from 
the Bagmati River, near to the Laboratory school, Kirtipur. The GPS of the sampling site is $27^{\circ} 40^{\prime} 32.31^{\prime \prime} \mathrm{N}$ and $85^{\circ} 17^{\prime}$ $45.20^{\prime \prime}$ E. The sample was collected in jar. The temperature was recorded in the site using Mercury filled Celsius thermometer. Then, the sample was carried to the laboratory for further analysis of other physico-chemical parameters, whereas the other samples were carried to home for the further process.

The water samples were kept in four buckets of 7.5 liters. In three buckets, Vetiver plants were planted whereas one bucket was kept as a control. In each of the three buckets, nine Vetiver plants were planted and physico-chemical parameters were analyzed for one month at 10-day intervals.

\subsection{Methods}

Table 1. Methods of measuring different parameters

\begin{tabular}{|c|c|c|}
\hline Parameters & Methods & Instruments \\
\hline Temperature & - & Celsius Thermometer \\
\hline $\mathrm{pH}$ & - & pH-Meter \\
\hline Conductivity & - & Conductivity meter \\
\hline Alkalinity & Acid-Base Titration & - \\
\hline Chloride & Argentometric & - \\
\hline Hardness & EDTAMethod & - \\
\hline BOD 5 & $\begin{array}{c}\text { Winkler's Iodometric } \\
\text { Method }\end{array}$ & - \\
\hline Nitrate & $\begin{array}{c}\text { Phenol Disulphonic } \\
\text { acid method }\end{array}$ & Spectrophoto-meter \\
\hline Phosphate & $\begin{array}{c}\text { Calorimetric method } \\
\text { Spectrophoto-meter }\end{array}$ \\
\hline
\end{tabular}

\section{Result and Discussion}

\subsection{Physical Parameters of Wastewater after Treatment}

\section{Temperature}

The water temperature plays an important factor which influences the chemical, bio-chemical characteristics of water body. Increased temperature accelerates the chemical reaction in water that affects the dissolve oxygen level in water and also implies the taste and odor (APHA [6], 1995).

The temperature of the sample water (treated and untreated) was found to be in same ranges. The temperature change was independent of treatment at the same sampling time where as it was found to be different in different sampling time.

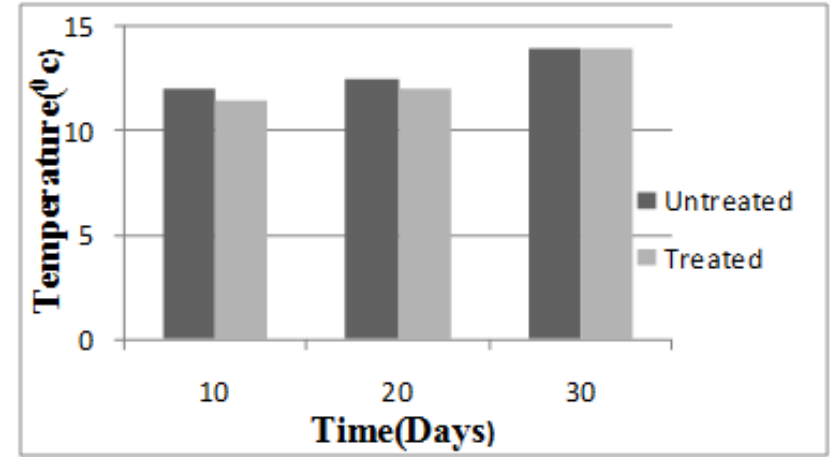

Figure 2. Temperature of Untreated and Treated Wastewater

\subsection{Chemical Parameter of Wastewater}

The wastewater showed slight change in the parameters like $\mathrm{pH}$, whereas electronic conductivity was decreased to normal level after treatment as compared between untreated wastewater and treated water.

\section{a) $\mathbf{p H}$}

$\mathrm{pH}$ indicates the intensity of acidity or alkalinity condition of the any solution. The water greater than 8.5 or less than 6.5 are regarded as polluted (Trivedy and Goel[7], 1986). Polluted water causes corrosion in pipes and releases toxic materials.

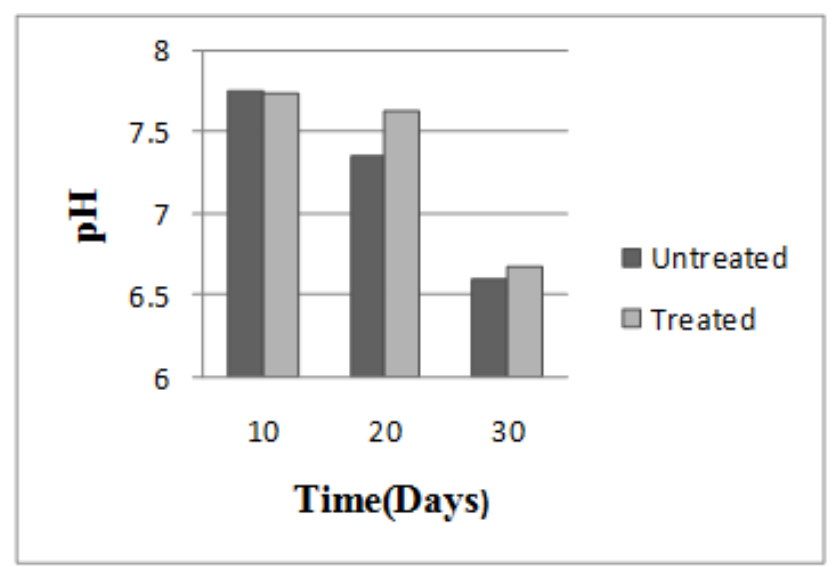

Figure 3. $\mathrm{pH}$ of Untreated and Treated Wastewater

The $\mathrm{pH}$ values of the water sample during the experiment were within the acceptable limit. The average $\mathrm{pH}$ range for the wastewater with treatment and without treatment was found to be 7.31 and 7.36, which is in acceptable limit. As shown in the figure 3, both of the water sample treated and untreated were found decreasing along the time interval of 10 days.

\section{b) Conductivity}

Conductivity of water increases with the increase in degree of pollution as there is increasing in prevalence of dissolved salt and solids. The water with conductivity more than $20 \mu \mathrm{S} / \mathrm{cm}$ is not suitable for irrigation (Trivedy and Goel [7], 1986). The average electronic conductivity of water 
sample with vetiver plant was obtained to be $625.33 \mu \mathrm{s} / \mathrm{cm}$ whereas the water sample without vetiver plant was obtained to be $746 \mu \mathrm{s} / \mathrm{cm}$. The electronic conductivity of the treated water sample was found to be decreasing, comparing to the untreated wastewater as shown in figure 4 . The reducing percentage of electronic conductivity was $46.52 \%$.

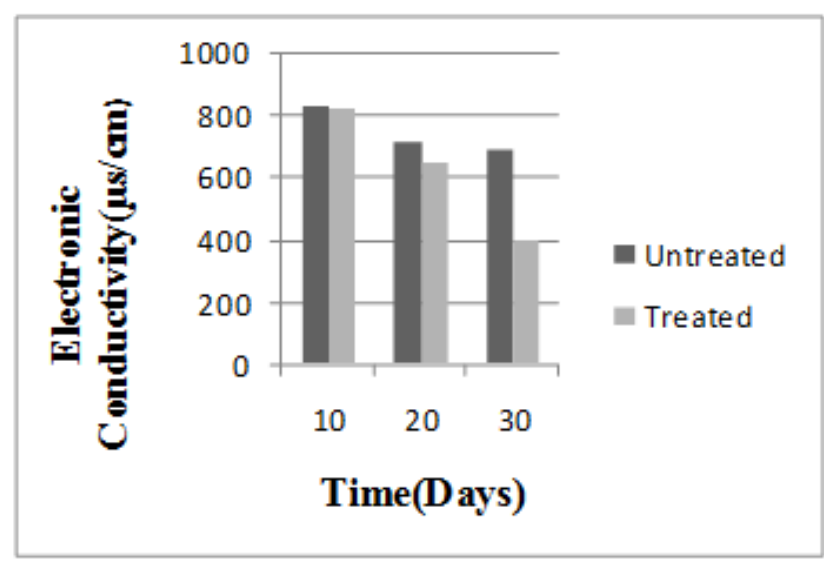

Figure 4. Electronic Conductivity of Untreated and Treated Wastewater

\section{c) Alkalinity}

Alkalinity of natural water is generally due to the presence of bicarbonates and it favors to zooplankton population. Higher the value of alkalinity indicates the presence of bicarbonates, carbonates and hydroxide in water body (Jain [8], 2000). pH has direct relationship with total alkalinity as reported by Bharadwaj and Sharma([9],1999).

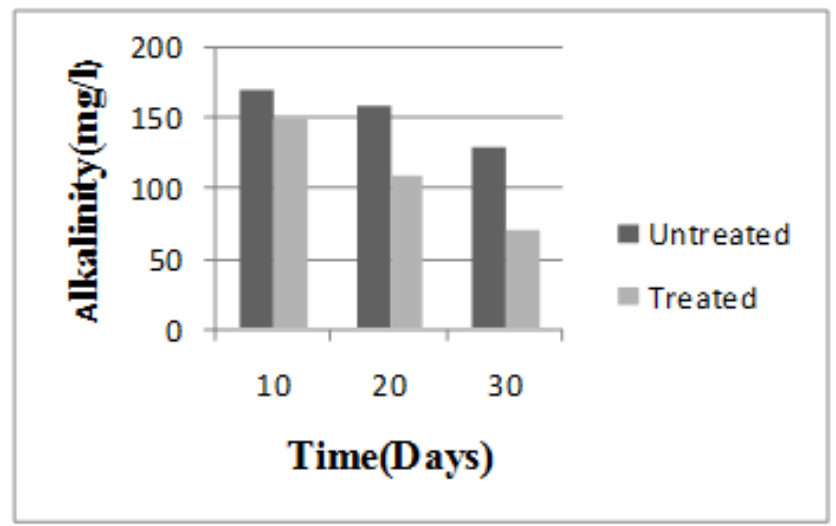

Figure 5. Alkalinity of Untreated and Treated Wastewater

Average alkalinity of the untreated water was obtained to be $153.33 \mathrm{mg} / \mathrm{L}$ whereas treated water was found to be $110 \mathrm{mg} / \mathrm{L}$. It has been observed slightly lower decrease in alkalinity in untreated water as compared to treated water (Figure 5). On the one month, the concentration of alkalinity was reduced by $22.22 \%$.

\section{d) Hardness}

On the basis of hardness values, Kannan [10] (1991) has classified water in the following manner: $0-60 \mathrm{mg} / \mathrm{L}$ soft, $61-120 \mathrm{mg} / \mathrm{L}$ moderately hard and $121-160 \mathrm{mg} / \mathrm{L}$ hard and
$<180 \mathrm{mg} / \mathrm{L}$ hard. Average hardness of the treated and untreated wastewater was found to be $122 \mathrm{mg} / \mathrm{L}$ and $139.33 \mathrm{mg} / \mathrm{L}$ i.e. the hardness of the wastewater was within the permissible limits. On the one month of wastewater treatment the concentration of hardness was reduced by $46.42 \%$. Hardness below $300 \mathrm{mg} / \mathrm{L}$ is considered as portable but beyond this limits cause gastro-intestinal irritation (ICMR [11], 1975). Mohanta and Patra [12] (2000) stated that addition of sewage, detergents and large scale human use cause elevation of hardness of water.

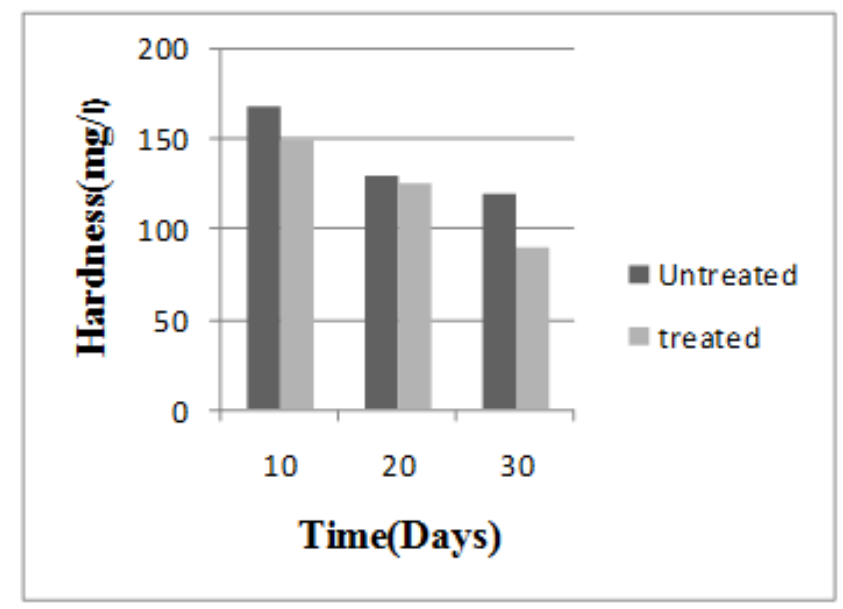

Figure 6. Hardness of Untreated and Treated Wastewater

\section{e) Chloride}

Chloride in water is originated from natural resources in the form of $\mathrm{NaCl}, \mathrm{KCl}$ etc. The increased concentration of chloride is considered as an indicator of eutrophication (Haynes [13], 1963) and pollution due to sewage (Chourasia and Adoni [14], 1985). If chloride is present in useful amount, they help in purification of water against infectious germs and make it suitable for drinking, fishery, irrigation and other various purposes as chlorine is an essential nutrient for aquatic creatures, plants, animals and human beings. Chloride tolerance limit for aquatic life survival is $<600 \mathrm{mg} / \mathrm{L}$ and $1-100 \mathrm{mg} / \mathrm{L}$ for irrigation (Trivedy [8], 1986).

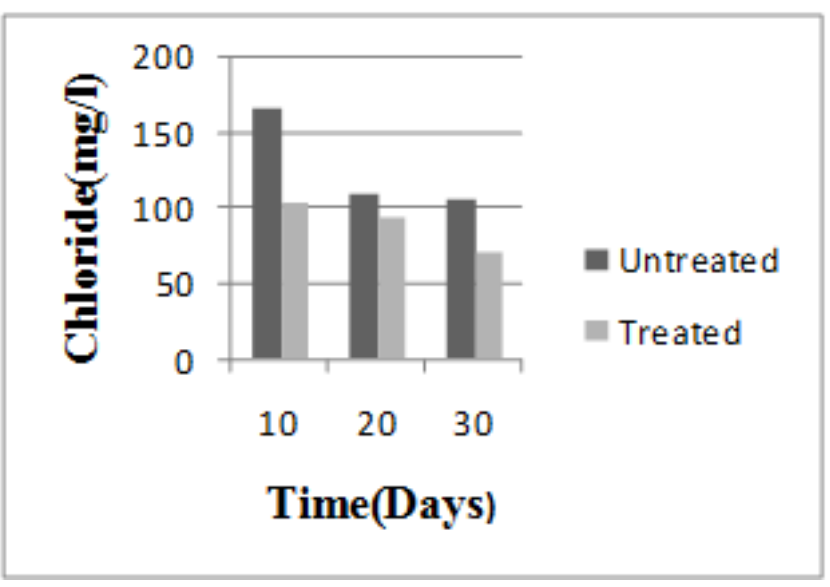

Figure 7. Chloride of Untreated and Treated Wastewater 
Chloride of the initial wastewater sample was found to be $123.54 \mathrm{mg} / \mathrm{L}$ and after the plantation of vetiver plant in that sample it was reduced to 89.03 after 30 days of plantation.

\section{f) Biological Oxygen Demand}

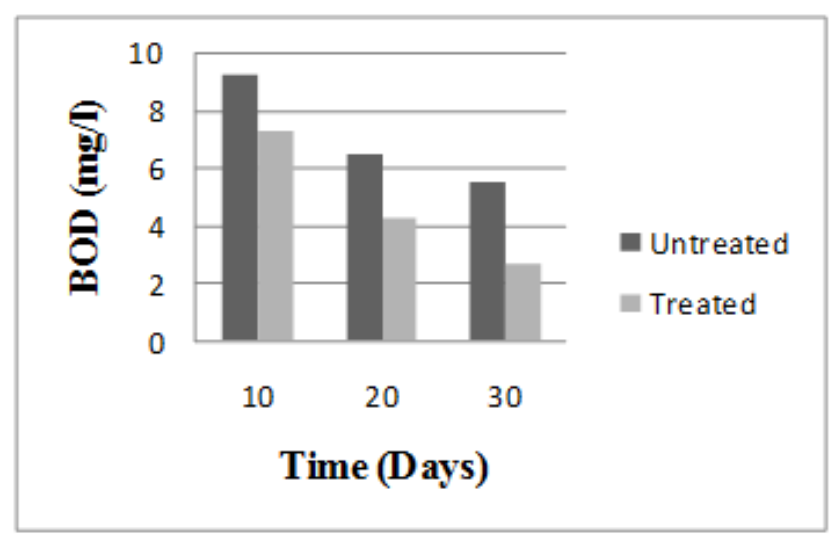

Figure 8. BOD of Untreated and Treated Wastewater

Dissolving Oxygen in water is very important for the survival of aquatic lives which consume the chemical and biological contaminating agents as a source of their food and help to maintain the water quality. Initially while calculating the DO of the wastewater sample of Bagmati was found to be $0 \mathrm{mg} / 1$ which means the water sample is not suitable for the survival of aquatic life. Bagmati River is highly polluted and there is no possibility for the existence of fresh water organisms (Trivedy and Goel [7], 1986). The reason behind this may be due to mixing of untreated sewage and effluents in the river water.

After the 50 times dilution in wastewater, BOD was obtained to be $7.11 \mathrm{mg} / \mathrm{L}$ in average, whereas same sample with vetiver plant, BOD was obtained to be $4.77 \mathrm{mg} / \mathrm{L}$ in average.

\section{g) Nitrate}

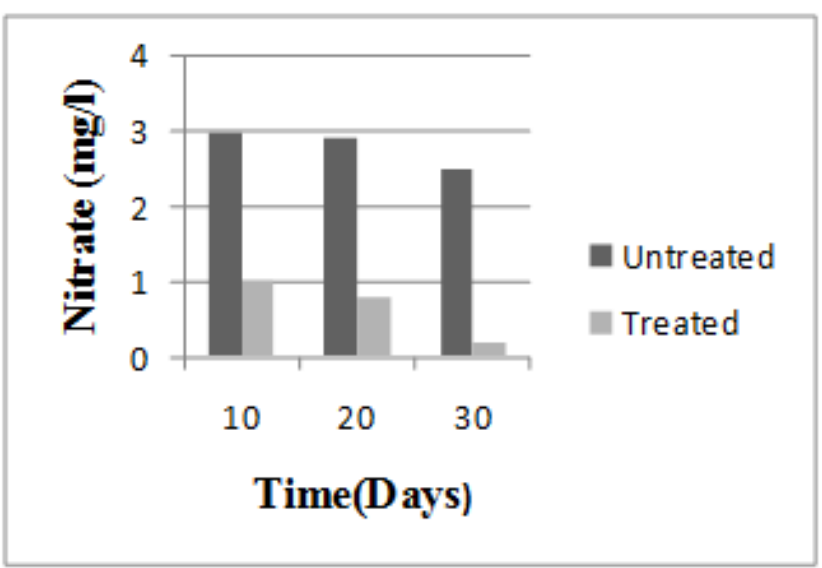

Figure 9. Nitrate of Untreated and Treated Wastewater

Nitrates are formed in water due to oxidation of ammonia by bacterial action and their presence indicates that nitrogenous organic matter is under nitrification. The presence of little higher value in water is an indication of pollution in the river and will cause eutrophication as a nutrient and reduce water quality. The natural level of nitrate in water is $0.1 \mathrm{mg} / \mathrm{L}$. The standard guideline of nitrate that is given by NWQS is $0.2-10 \mathrm{mg} / \mathrm{L}$ for the protestation of aquatic life. The concentration of nitrate of initial sample was obtained as $3.3 \mathrm{mg} / \mathrm{L}$, whereas it was reduced to $0.2 \mathrm{mg} / \mathrm{L}$ after 30-day plantation of vetiver plant in the water sample. Sharp decline was observed in the value of Nitrate 10 days after the introduction of vetiver plant in the sample water and then decreased slowly to $0.2 \mathrm{mg} / \mathrm{L}$ after 30 days (Figure 9).Trivedy and Goel [7] (1986) reported that Domestic and agricultural runoff wastewater contain highest concentration of nitrate as ammonia and nitrogenous fertilizers are used in agricultural food production.

\section{h) Phosphate}

Phosphorus occurs in water in the form of phosphate or the inorganic phosphorus which are collectively termed as total phosphorous. Phosphate acts as nutrient for plant growth and high concentration of phosphate is also an indication of eutrophy. When it is above the range $0.005-0.20 \mathrm{mg} / \mathrm{L}$, the water is considered as polluted (ENPHO [15], 2003).

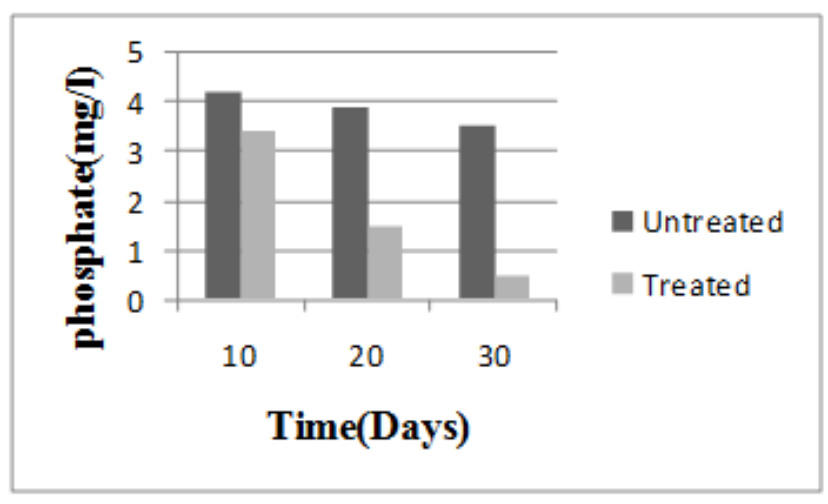

Figure 10: Phosphate of Untreated and Treated Wastewater

The total phosphorus of initial sample of wastewater was obtained to be $4.3 \mathrm{mg} / \mathrm{L}$ which was reduced to $0.5 \mathrm{mg} / \mathrm{L}$ after 30 days. Sharp decrease of phosphate was observed in water treated with vetiver plant, while slight decrease was observed in untreated water (Figure 10). Vetiver plant seems very effective in treating polluted water containing high phosphate.

\section{Conclusions}

A large number of factors and conditions influence the correlations between different pairs of Physico-chemical parameters of water samples directly or indirectly. The physico-chemical parameters of the water samples were analyzed with and without the Vetiver plant for one month. The physical parameters of wastewater showed slight change in the parameters like $\mathrm{pH}$ and temperature, whereas electronic conductivity was decreased to normal level after treatment as compared between untreated wastewater and 
treated water. With the use of Vetiver plants in the wastewater, the chemical parameters (BOD, Alkalinity, Hardness, Nitrate, Phosphate, Chloride) are gradually reduced, complying with the Guideline values set by Nepal Water Quality Standards.

Hence, Vetiver plantation is one of the best methods for wastewater treatment for the country like Nepal, as the different modern technologies for wastewater treatment are very costly and require good technical knowledge on handling the process.

\section{Acknowledgements}

We are very grateful to Central Department of Environmental Science, Tribhuvan University, Kathmandu, Nepal for laboratory facility. We sincerely acknowledge the contribution of Mr. Ramjee Shrestha (STAGE Nepal), Mr. Ramesh Basnet, Mr. Nabin Nepal, peer reviewers, English expert and all experts for their appropriate and constructive suggestions to improve the work.

\section{REFRESENCES}

[1] Stikker, A., Water Today and Tomorrow, Prospects for Overcoming Scarcity, Futures, Vol. 30, No. 1, Elsevier Science Ltd., Great Britain, 1998.

[2] Lasat M. M.-Reviews and analyses-Phytoextraction of Toxic metals; A review of biological mechanisms". Journal of Environmental; A review of biological mechanism'. Journal of Environments Quality (JEQ) Volume 31 Pp. 109 - 120. 2002.

[3] Erakhrumen, A.A., Phytoremediation:an environmentally sound technology for pollution prevention, control and remediation in developing countries. Educational Research and Review,2 (7):151-156, 2007.

[4] Truong, P.N., The Global Impact of Vetiver Grass Technology on the Environment. Proc. Second Intern. Vetiver Conf. Thailand, January 2000.

[5] Truong, P. and Hart, B., Vetiver System for Wastewater Treatment. Technical Bulletin No. 2001/2. Pacific Rim Vetiver Network. Royal Development Projects Board, Bangkok, Thailand, 2001.

[6] APHA, AWWA, WEF. Standard Methods for the Examination of Water and Wastewater. (American Public Health Association, American Water Works Association, and Water Environment Federation, Washington DC, 2005).

[7] Trivedy, R.and Goel,P.K.., Chemical and Biological methods of Water Pollution Studies. Department of Environmental Pollution, Kard,India, 1986.

[8] Jain, C., Groundwater quality in sugar districts Madhya Pradesh, India. Jr.Env.Health, 42(4):151-158. 2000.

[9] Bharadwaj, K. and Sharma, L., Study of some physico-chemical characteristics of a sewage fertilized seasonal pond of Udaipur (Rajasthan). J. Env.Poll. 6(4):255-260.1999.

[10] Kannan K., Fundamentals of Environmental Pollution, S. Chand and Company Ltd, New Delhi. 1991.

[11] ICMR, Manual of standards of quality for drinking water supplies. ICMR, New Delhi. 1975

[12] Mohanta B. K. and Patra A. K., Studies on the water quality index of river SanamaChhakandana at Keonjhar Garh, Orissa. Poll.Ress.19:377-385, 2000.

[13] Haynes, H.B.N., The biology of the polluted waters. Liverpool University Press, Liverpool, U.K., 1963.

[14] Chourasia, S.K. and Adoni, A.D., Zooplankton dynamics in a shallow entropic lake. Indian Proceedings of Natural Samples, Pure and Applied Limnology (Editior: A.B.Adoni). Bulletein of Botanical Society, Sagar, India, 32, 1985.

[15] ENPHO, South Asian Trans-Boundary Water Quality Monitoring (SATWQM) Data, 2003.

[16] Gupta, P. Agarwal, S. Assessment of Physico-chemical Parameters of Various Lakes of Jaipur, Rajasthan, India, 2011.

[17] Simpi B., Horemath S.M, Murthy K.N.S, Patel A.,Analysis of Water Quality UsingPhysico-chemical Parameters. Hosahalli Tank in Shimoga District, Karnataka, India, 2011

[18] Ash, R. and Truong, P., The Use of Vetiver Grass for Sewerage Treatment. Paper for Sewage management QEPA Conference, Cairns, Australia, 2004.

[19] [19]Bagmati Area Sewerage Construction/Rehabilitation Project (BASP). The Implementation and Monitoring of the Bagmati Area Sewerage Construction/Rehabilitation Project (BASP). Kathmandu: BASP, 2002 (Brochure).

[20] Troung, p., and Baker, D., Vetiver Grass System for Environmental Protection. Technical Bulletin no.1998/1, Pacific Rim Vetiver Network, Office of the Royal Development Projects Board, Bangkok, Thailand, 1998.

[21] Ghosh, R. Studies on Physico-Chemical Parameters and Benthic Fauna of Bagmati River, Kathmandu, Nepal-64p

[22] Truong, p. Wangner, S. Vieritz, A. Smeal, C. Response of Vetiver Grass to Extreme Nitrogen and Phosphorus Supply.

[23] Truong, P.N., Mason, F., Waters, D. and Moody, P., Application of Vetiver Grass Technology in off-site pollution control. I. Trapping agrochemicals and nutrients in agricultural lands. Proc. Second Intern. Vetiver Conf. Thailand, January 2000.

[24] Gautam, R., Shrestha, J.R., Shrestha, G.K.C., Assessment of River Water Intrusion at the Periphery of Bagmati River in Kathmandu Valley. Forest Resource Assessment Nepal, Babarmahal, Kathmandu,. 2013.

[25] Zheng, C., Tu C. and Chen H., Preliminary Study on Purification of Eutrophic Water with Vetiver. Proc. International Vetiver workshop, Fuzhou, China, October 1997.

[26] Chomchalow. The Role of Vetiver in Controlling Water Quantity and Treating. Water Quality: An Overview with Special Reference to Thailand, 145-161, 2003. 